\title{
Effects of NPK Briquette on Rice (Oryza sativa) in Tidal Flooded Ecosystem
}

\author{
M. Sh. Islam ${ }^{1 *}$, F. Rahman ${ }^{2}$ and A. T. M. S. Hossain ${ }^{2}$ \\ ${ }^{1}$ Agronomy Division, Bangladesh Rice Research Institute, Gazipur-1701, Bangladesh \\ ${ }^{2}$ Soil Science Division, Bangladesh Rice Research Institute, Gazipur-1701, Bangladesh \\ *Corresponding author and Email: mshahid7862004@yahoo.co.uk
}

Received: 5 April $2011 \quad$ Accepted: 26 November 2011

\begin{abstract}
An experiment was conducted at the Bangladesh Rice Research Institute, R/S Sagordi farm, Barisal to evaluate the effectiveness of NPK briquette on rice in tidal flooded soil condition during Boro season, 2010. NPK briquettes of size $2.4 \mathrm{~g}$ and $3.4 \mathrm{~g}$ were compared with urea super granules (USG) and prilled urea (PU), each supplemented with PKS. The results showed that NPK briquettes, USG and PU produced statistically similar grain yield. N-treated plots (briquettes, USG and PU) gave significantly higher grain yield than $\mathrm{N}$ control. The highest grain yield $\left(7.47 \mathrm{t} \mathrm{ha}^{-1}\right)$ was observed in NPK briquette $(2.4 \mathrm{~g} \times 2)$ followed by PU. There was no significant difference between $\mathrm{N}$ control and absolute control plots in respect of yield indicating that $\mathrm{N}$ was the only yield limiting factor under that condition. The NPK briquettes showed higher agronomic efficiency than PU and USG. The small size briquettes $\left(2.4 \mathrm{~g}\right.$ ) could save $33 \mathrm{~kg} \mathrm{~N} \mathrm{ha}^{-1}$ compared to recommended PU. There was no residual effect of NPK briquettes on soil chemical properties. The NPK briquettes were found beneficial to the farmers in tidal ecosystem.
\end{abstract}

\section{Keywords: NPK briquette, USG, prilled urea, agronomic efficiency, nutrient uptake}

\section{Introduction}

Generally, the farmers of our country use non urea fertilizer as basal during final land preparation. In tidal flooded condition, most of the applied fertilizers are lost through different ways. Deep placement of all essential fertilizers may be more efficient and farmers can be more benefited from this compared to broadcast method. The use of NPK briquette, which is a mixture of urea, triple super phosphate (TSP) and muriate of potash (MOP) may help to reduce the loss of nutrients in tidal flooded ecosystem.

Farmers in Vietnam and Cambodia obtained 25 $\%$ higher yields with deep placement of NPK briquettes over the broadcasting of fertilizer (IFDC, 2007). In Bangladesh, yield of rice was increased by $15-25 \%$, while expenditure on commercial fertilizer was decreased by $24-32 \%$ when fertilizer briquettes were used as the source of plant nutrients. Deep placement of fertilizer briquettes also offered environmental and economic benefits (IFPRI, 2004). A national survey conducted in Bangladesh during 2004 showed that more than 1800 briquette-making machines had been manufactured and sold and about 550000 rice farmers were using the technology in their fields (IFDC, 2007).

In tidal ecosystem, nutrient management strategies would be different from other ecosystem. Because, applied NPK fertilizers are washed-out from rice field during tidal flood. So, deep placement of all fertilizers would be effective rather than broadcasting. Moreover, sufficient amount of nutrients are added to the soil during tidal sedimentation. Costal soils are blessed with tidal deposition containing organic matter and plant nutrients consisting of N, P, K and other materials (Neubauer et al., 2002; 
Chandrajith et al., 2008). Tidal sediment in the BRRI, Barisal farm contains $1.8 \%$ organic carbon, 20 ppm P and 0.40 meq/100 g sediment K (Saleque, 2009 Personal communication), which can enrich the soil. So, the rate of NPK fertilizers would be less in that situation. A study was therefore undertaken on performance evaluation of different NPK briquettes and USG deep placement compared with traditional prilled urea broadcast in tidal ecosystem of Barisal region.

\section{Materials and Methods}

The experiment was conducted in Bangladesh Rice Research Institute (BRRI) research farm, Sagordi, Barisal under tidal flooded ecosystem during Boro season in 2010. The experimental land generally remains submerged in the wet season and is enriched with sufficient amount of tidal sediment. The initial soil had $\mathrm{pH} 5.6$, organic carbon $(\mathrm{OC})=1.7 \%$, available $\mathrm{P}=12$ ppm and exchangeable $\mathrm{K}=0.32 \mathrm{meq} / 100 \mathrm{~g}$ soil. Two sizes of NPK briquettes were used where the smaller size ( $2.4 \mathrm{~g})$ contains $29 \% \mathrm{~N}, 6$ $\% \mathrm{P}$ and $8 \% \mathrm{~K}$ and the big size ( $3.4 \mathrm{~g}$ ) contains $26 \% \mathrm{~N}, 6 \% \mathrm{P}$ and $11.5 \% \mathrm{~K}$. The study was conducted taking six treatments laid out in a randomized complete block design using three replications. The treatments were; $\mathrm{T}_{1}=\mathrm{NPK}$ briquette $(2.4 \mathrm{~g} \times 2$, which contains $87 \mathrm{~kg} \mathrm{~N}, 20$ $\left.\mathrm{kg} \mathrm{P} \& 25 \mathrm{~kg} \mathrm{~K} \mathrm{ha}^{-1}\right), \mathrm{T}_{2}=$ NPK briquette $(3.4 \mathrm{~g}$ $\times 1$, which contains $57 \mathrm{~kg} \mathrm{~N}, 15 \mathrm{~kg} \mathrm{P} \& 22 \mathrm{~kg} \mathrm{~K}$ $\mathrm{ha}^{-1}$ ), $\mathrm{T}_{3}=\mathrm{USG}$ (@84 kg ha ${ }^{-1} \mathrm{~N}+\mathrm{PKS}(26-41$ $\left.10 \mathrm{~kg} \mathrm{ha}^{-1}\right), \mathrm{T}_{4}=$ Prilled urea $\left(120 \mathrm{~kg} \mathrm{~N} \mathrm{ha}^{-1}\right)+$ PKS (26-41-10 kg ha $\left.{ }^{-1}\right), \mathrm{T}_{5}=\mathrm{N}$ control $\left(\mathrm{N}_{0}\right)+$ PKS (26-41-10 kg ha ${ }^{-1}$ ) and $\mathrm{T}_{6}=$ Absolute control.

The USG, PU and $\mathrm{N}$ control treated plots received @ 26-41-10 kg ha ${ }^{-1} \mathrm{P}, \mathrm{K} \& \mathrm{~S}$ through TSP, MP, and gypsum. The seedlings of BRRI dhan 29 were transplanted on 8 January by using with $20 \times 20 \mathrm{~cm}$ spacing. The TSP, MOP and Gypsum were applied as basal and NPK briquette and USG were applied 15 days after transplanting (DAT). The briquettes and USG were inserted 7 to $10 \mathrm{~cm}$ deep in the middle of every alternate 4 hills. Prilled urea was applied thrice at 20, $35 \& 50$ DAT. Plant height was measured and tiller number was counted at 30 and 60 DAT. Data on plant height and tillers hill ${ }^{1}$ at harvest, yield and yield components were recorded. Chemical analysis of $\mathrm{N}, \mathrm{P} \& \mathrm{~K}$ in grain, straw and post harvest soil was performed. The nutrient uptake and $\mathrm{N}$ use efficiency were calculated. The agronomic efficiency and recovery efficiency were estimated as:

$$
\text { i) } \quad \mathrm{E}_{\mathrm{a}}=\Delta \mathrm{Y} / \mathrm{N}_{\mathrm{r}}
$$$$
\text { ii) } \quad E_{\mathrm{r}}=\Delta \mathrm{N}_{\mathrm{p}} / \mathrm{N}_{\mathrm{r}}
$$

where, $\mathrm{E}_{\mathrm{a}}=$ Agronomic efficiency, $\Delta \mathrm{Y}=$ increased grain yield resulted from $\mathrm{N}$ application,

$\mathrm{N}_{\mathrm{r}}=\mathrm{N}$ rate $\left(\mathrm{kg} \mathrm{ha}^{-1}\right), \mathrm{E}_{\mathrm{r}}=$ Recovery efficiency and $\Delta \mathrm{N}_{\mathrm{p}}=$ increased plant $\mathrm{N}$ accumulation resulting from $\mathrm{N}$ fertilization.

\section{Results and Discussion}

\subsection{Growth parameters}

Taller plants and larger number of tillers hill ${ }^{-1}$ were observed in NPK briquette, USG and prilled urea treated plots compared to control plots both at 30 and 60 DAT (Table 1). The $2.4 \mathrm{~g}$ $\times 2$ size NPK briquettes obtained higher plant height and tiller number hill ${ }^{-1}$ compared to $3.4 \mathrm{~g}$ $\times 1$ size because of higher $\mathrm{N}$ rate. The differences among the treatments were larger at 60 DAT compared to 30 DAT. Higher plant height and higher number of tillers hill ${ }^{-1}$ was due to higher doses of $\mathrm{N}$ fertilizer application. 
Table 1. Plant height, tiller hill ${ }^{-1}$ of BRRI dhan 29 as influenced by NPK briquettes and USG, during Boro 2010

\begin{tabular}{|c|c|c|c|c|}
\hline \multirow[b]{2}{*}{ Treatments } & \multicolumn{2}{|c|}{ Plant height (cm) } & \multicolumn{2}{|c|}{ No. of tiller hill ${ }^{-1}$} \\
\hline & 30 DAT & 60 DAT & $30 \mathrm{DAT}$ & 60 DAT \\
\hline NPK briquette ( $2.4 \mathrm{~g}$ size two granules) & 57 & 78 & 5 & 16 \\
\hline NPK briquette ( $3.4 \mathrm{~g}$ size one granule) & 54 & 73 & 4 & 13 \\
\hline USG + PKS (26-41-10 kg ha $\left.{ }^{-1}\right)$ & 56 & 77 & 5 & 15 \\
\hline Prilled urea $\left(120 \mathrm{~kg} \mathrm{~N} \mathrm{ha}^{-1}\right)+\mathrm{PKS}$ & 55 & 80 & 5 & 16 \\
\hline $\mathrm{N}$ control (+ PKS 26-41-10 kg ha $\left.{ }^{-1}\right)$ & 49 & 70 & 4 & 8 \\
\hline Absolute control & 48 & 69 & 3 & 7 \\
\hline SE $\%$ & 2.6 & 3.4 & 0.52 & 1.2 \\
\hline $\mathrm{CV} \%$ & 3.1 & 5.3 & 2.3 & 3.6 \\
\hline
\end{tabular}

\subsection{Yield and yield components}

Significantly higher plant height and higher number of tillers at harvest were observed in NPK briquette (two $2.4 \mathrm{~g}$ size), USG and PU treated plots (Table 2). Significantly higher number of panicles $\mathrm{m}^{-2}$ was observed in PU treated plots, which was statistically similar to NPK briquette (two $2.4 \mathrm{~g}$ size) and USG. But significantly higher number of grains panicle ${ }^{-1}$ were observed in NPK briquettes (both size) and USG treated plots. The treatment effect on 1000 grain weight was insignificant. The higher grain yield were observed in NPK briquette $(2.4 \mathrm{~g} \times$ 2), USG and PU treated plots which were statistically similar to NPK briquette $(3.4 \mathrm{~g} \times 1)$ (Table 2). Significantly higher grain yield was observed in $\mathrm{N}$-treated plots over $\mathrm{N}$ control and absolute control. The highest grain yield of $7.47 \mathrm{t}$ $\mathrm{ha}^{-1}$ was observed in NPK briquette $(2.4 \mathrm{~g} \times 2)$ which was closely followed by prilled urea treated plots $\left(7.33 \mathrm{t} \mathrm{ha}^{-1}\right)$. Higher yield with $2.4 \mathrm{~g}$ $\times 2$ size NPK briquette compared to $3.4 \times 1$ size was due to higher $\mathrm{N}$ rates $(87 \mathrm{~kg})$. The crop with
$3.4 \mathrm{~g} \times 1$ size NPK briquette suffered from $\mathrm{N}$ deficiency at later growth stage as there was lower amount of $\mathrm{N}(57 \mathrm{~kg})$. There was no significant difference in grain yield between $\mathrm{N}$ control and absolute control plots which indicates that $\mathrm{N}$ was the only yield limiting factor in tidal flooded condition. Higher level of sterility was observed in prilled urea treated plots compared to other treatments.

On the other hand, IFDC (2007) reported that deep placement of fertilizers had increased rice yield by $22 \%$ over broadcasting and decreased urea use by $47 \%$. The urea briquettes increased grain yield of rice over split application of urea and the additional yield from 5 to $83 \%$ (Kadam, 2001). Kapoor et al. (2008) reported that significantly higher grain yield was observed with deep placement of NPK briquette compared to broadcast application. Durguda et al. (2008) also reported that higher grain yield was observed in rice with DAP briquettes compared to urea. 
Table 2. Plant height, tiller hill ${ }^{-1}$, yield components and grain yield of BRRI dhan29 as influenced by NPK briquette and USG during Boro, 2010

\begin{tabular}{cccccccc}
\hline Treatments & $\begin{array}{c}\text { Plant } \\
\text { ht. }(\mathrm{cm})\end{array}$ & $\begin{array}{c}\text { Tiller } \\
\text { hill }\end{array}$ & $\begin{array}{c}\text { Panicle } \\
\mathrm{m}^{-2}\end{array}$ & $\begin{array}{c}\text { Grain } \\
\text { panicle }^{-1}\end{array}$ & $\begin{array}{c}1000 \mathrm{G} . \\
\text { wt. }(\mathrm{g})\end{array}$ & $\begin{array}{c}\text { Yield } \\
\left(\mathrm{t} \mathrm{ha}^{-1}\right)\end{array}$ & $\begin{array}{c}\text { Sterility } \\
\%\end{array}$ \\
\hline $\mathrm{T}_{1}{ }^{*}$ & 103.0 & 12.3 & 250 & 139 & 23.5 & 7.47 & 13 \\
$\mathrm{~T}_{2}$ & 98.3 & 10.7 & 233 & 138 & 23.1 & 7.08 & 10 \\
$\mathrm{~T}_{3}$ & 102.0 & 11.7 & 250 & 138 & 23.2 & 7.23 & 15 \\
$\mathrm{~T}_{4}$ & 102.0 & 13.0 & 275 & 105 & 23.4 & 7.33 & 20 \\
$\mathrm{~T}_{5}$ & 85.7 & 9.7 & 192 & 95 & 24.1 & 3.84 & 11 \\
$\mathrm{~T}_{6}$ & 84.7 & 9.0 & 200 & 89 & 24.0 & 3.60 & 14 \\
\hline LSD $(5 \%)$ & 6.28 & 3.01 & 61.58 & 33.6 & $\mathrm{NS}$ & 0.868 & 6.5 \\
$\mathrm{CV} \%$ & 3.6 & 15.0 & 14.5 & 13.8 & 5.7 & 7.8 & 20.8 \\
\hline
\end{tabular}

${ }^{*} \mathrm{~T}_{1}=$ NPK briquette $(2.4 \mathrm{~g} \times 2), \mathrm{T}_{2}=\mathrm{NPK}$ briquette $(3.4 \mathrm{~g} \times 1), \mathrm{T}_{3}=\mathrm{USG}\left(@ 84 \mathrm{~kg} \mathrm{ha}^{-1} \mathrm{~N}\right)+\mathrm{PKS}(26-41-10 \mathrm{~kg}$ $\left.\mathrm{ha}^{-1}\right), \mathrm{T}_{4}=$ Prilled urea $\left(120 \mathrm{~kg} \mathrm{~N} \mathrm{ha}^{-1}\right)+$ PKS $\left(26-41-10 \mathrm{~kg} \mathrm{ha}^{-1}\right), \mathrm{T}_{5}=\mathrm{N}$ control + PKS (26-41-10 $\left.\mathrm{kg} \mathrm{ha}^{-1}\right) \& \mathrm{~T}_{6}=$ Absolute control

\subsection{Nutrient uptake by grain and straw and nutrient use efficiency}

As in case of grain yield and yield components, higher N, P \& K uptake was observed in NPK briquette $(2.4 \mathrm{~g} \times 2)$, USG and prilled urea treated plots, which were resulted from higher grain yield and higher nutrient concentration in grains and straw sample (Figure 1a,b,c). The highest 77.7 and $56.9 \mathrm{~kg} \mathrm{ha}^{-1}$ of $\mathrm{N}$ were uptaken by grain and straw, respectively, from NPK briquette $(2.4 \mathrm{~g} \times 2)$ treated plots (Figure 1a). The highest 20.2 and $12.3 \mathrm{~kg} \mathrm{ha}^{-1}$ of $\mathrm{P}$ were removed by grain and straw respectively, from NPK briquette $(2.4 \mathrm{~g} \times 2)$ treated plots (Figure 1b). The highest 26.2 and $138.8 \mathrm{~kg} \mathrm{ha}^{-1}$ of $\mathrm{K}$ were uptaken by grain and straw respectively, from NPK briquette $(2.4 \mathrm{~g} \times 2)$ treated plots (Figure 1c). Much lower (30 to $50 \%$ ) NPK uptake by grain and straw was observed in $\mathrm{N}$ control and absolute control compared to $\mathrm{N}$ treated plots mostly due to lower grain and straw yield. Similar $\mathrm{P}$ uptake by grain and straw in $\mathrm{T}_{5}$ and $\mathrm{T}_{6}$ treated plots indicated that TSP application in $\mathrm{T}_{5}$ plot has no effect on yield and $\mathrm{P}$ uptake by the plants. Five to six time higher $\mathrm{K}$ uptake by straw than by grain in $T_{1}$ to $T_{4}$ was mainly due to higher straw yield, high initial soil $\mathrm{K}$ and luxury $\mathrm{K}$ consumption.

Bigger size NPK briquettes (3.4 g) showed the highest value of $\mathrm{N}$ use efficiency (Agronomic and recovery) because of lower $\mathrm{N}$ dose $(57 \mathrm{~kg})$ (Table 3) followed by smaller size $(2.4 \mathrm{~g} \times 2)$ and USG, although the crop showed $\mathrm{N}$ deficiency at booting to flowering stage in $3.4 \mathrm{~g}$ size treated plots. Deep placement of briquettes and USG increased nitrogen use efficiency by keeping most of the urea nitrogen in the soil, close to plant roots and out of the irrigation water (IFDC, 2007). The highest $\mathrm{N}$ recovery (93 $\%$ ) was estimated in $\mathrm{T}_{2}$ followed by $\mathrm{T}_{1}$; much higher agronomic efficiency for $\mathrm{N}$ in $\mathrm{T}_{1}$ and $\mathrm{T}_{2}$ indicates that NPK briquettes are efficient enough to produce higher yield with minimum $\mathrm{N}$ dose and better nutrient uptake. Kapoor et al. (2008) also observed that significantly higher N, $\mathrm{P}$, and $\mathrm{K}$ uptake and $\mathrm{N}$ and $\mathrm{P}$ use efficiencies with deep placement of NPK briquette compared to broadcast application. 


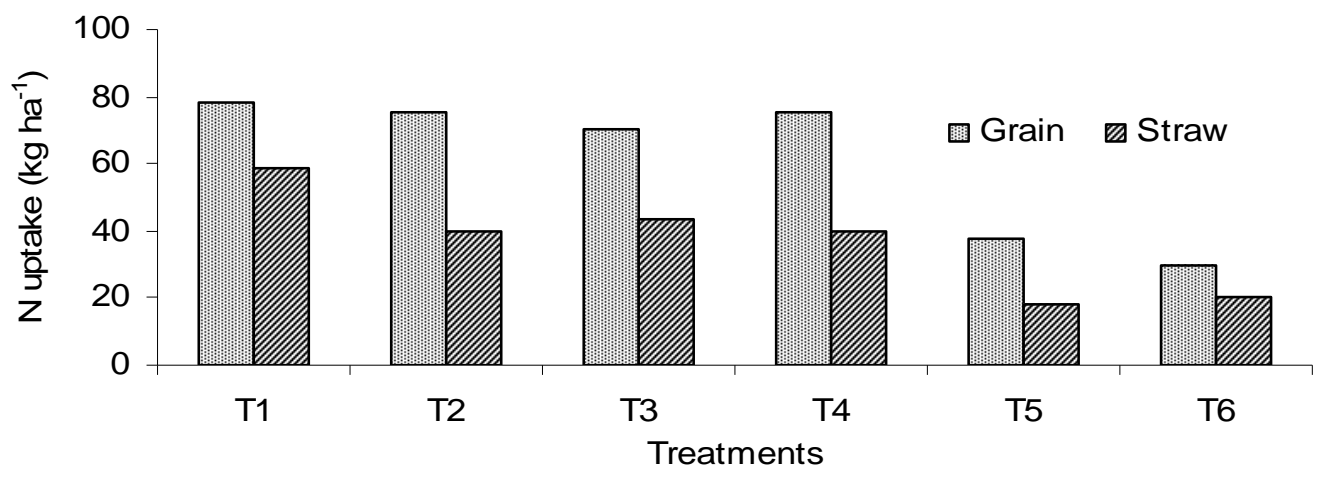

Fig. 1a. $\mathrm{N}$ uptake by grain and straw as influenced by different treatments.



Fig. 1b. $P$ uptake by grain and straw as influenced by different treatments.

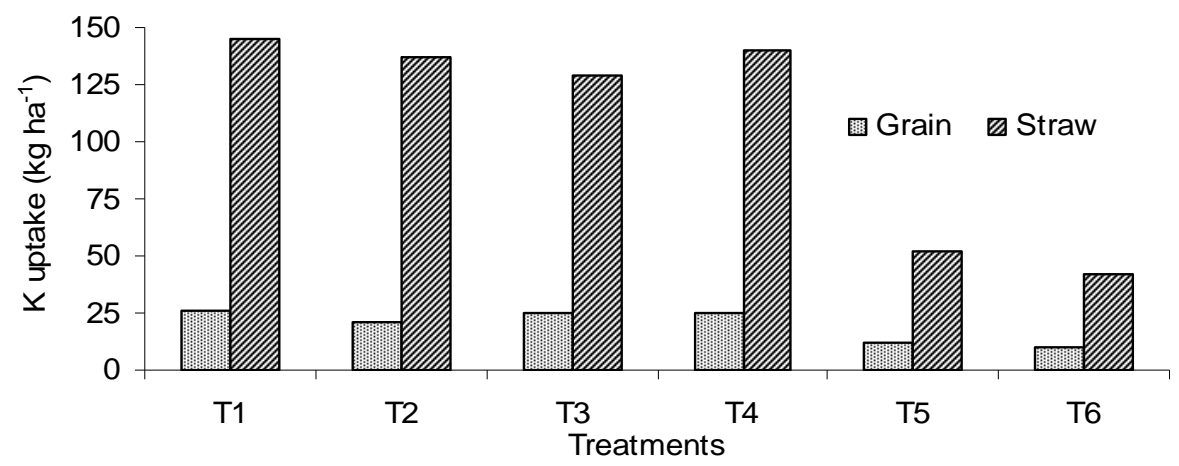

Fig. 1c. K uptake by grain and straw as influenced by different treatments.

$\mathrm{T}_{1}=\mathrm{NPK}$ briquette $(2.4 \mathrm{~g} \times 2), \mathrm{T}_{2}=\mathrm{NPK}$ briquette $(3.4 \mathrm{~g} \times 1), \mathrm{T}_{3}=\mathrm{USG}\left(@ 84 \mathrm{~kg} \mathrm{ha}^{-1} \mathrm{~N}\right)+\mathrm{PKS}(26-41-10 \mathrm{~kg}$ $\left.\mathrm{ha}^{-1}\right), \mathrm{T}_{4}=$ Prilled urea $\left(120 \mathrm{~kg} \mathrm{~N} \mathrm{ha}^{-1}\right)+$ PKS $\left(26-41-10 \mathrm{~kg} \mathrm{ha}^{-1}\right), \mathrm{T}_{5}=\mathrm{N}$ control + PKS $\left(26-41-10 \mathrm{~kg} \mathrm{ha}^{-1}\right) \& \mathrm{~T}_{6}=$ Absolute control 
Table 3. Agronomic and recovery efficiency for $\mathrm{N}$ as influenced by different treatments during Boro, 2010

\begin{tabular}{lcc}
\hline \multicolumn{1}{c}{ Treatments } & Agronomic efficiency & Recovery efficiency \\
\hline NPK briquette $(2.4 \mathrm{~g} \times 2)$ & 4.2 & 88 \\
NPK briquette $(3.4 \mathrm{~g} \times 1)$ & 5.7 & 93 \\
USG + PKS $(26-41-10)$ & 4.0 & 66 \\
Prilled urea $\left(120 \mathrm{~kg} \mathrm{~N} \mathrm{ha}^{-1}\right)+$ PKS $(26-41-10)$ & 2.9 & 46 \\
N control + PKS $(26-41-10-5)$ & - & - \\
\hline
\end{tabular}

Table 4. Chemical properties of post harvest soil of the experimental plots during Boro 2010

\begin{tabular}{lccccc}
\hline Treatments & $\mathrm{pH}$ & $\begin{array}{c}\text { Organic } \\
\text { Carbon }(\%)\end{array}$ & $\mathrm{N}(\%)$ & $\mathrm{P}(\mathrm{ppm})$ & $\mathrm{K}(\mathrm{meq} / 100 \mathrm{~g})$ \\
\hline NPK briquitte $(2.4 \times 2)$ & 5.6 & 1.52 & 0.15 & 13.33 & 0.21 \\
NPK briquitte $(3.4 \times 1)$ & 5.6 & 1.44 & 0.14 & 12.67 & 0.18 \\
USG + PKS $\left(26-41-10 \mathrm{~kg} \mathrm{ha}^{-1}\right)$ & 5.5 & 1.66 & 0.17 & 15.00 & 0.18 \\
Prilled urea $\left(120 \mathrm{~kg} \mathrm{~N} \mathrm{ha}^{-1}\right)+\mathrm{PKS}$ & 5.5 & 1.49 & 0.15 & 14.00 & 0.19 \\
N control + PKS $(26-41-10)$ & 5.5 & 1.43 & 0.14 & 16.33 & 0.19 \\
Absolute control & 5.6 & 1.58 & 0.16 & 11.33 & 0.19 \\
\hline LSD $(5 \%)$ & $\mathrm{NS}$ & 0.145 & - & 2.144 & 0.0139 \\
CV \% & 2.0 & 5.3 & - & 8.6 & 4.1 \\
\hline
\end{tabular}

\subsection{Post harvest soil analysis}

The results of post harvest soil analysis indicated that there was no change in soil $\mathrm{pH}$ among the treatments. However, there was higher OC \% in USG treated plots, higher $\mathrm{P}$ in $\mathrm{N}$ control plots and higher K in NPK briquette $(2.4 \mathrm{~g} \times 2)$ treated plots (Table 4). This result indicates that there was no residual effect of NPK briquettes and USG on total $\mathrm{N}$, available $\mathrm{P}$ and exchangeable $\mathrm{K}$ in soil.

\section{Conclusions}

The NPK briquette $(2.4 \mathrm{~g} \times 2)$ showed better performance in terms of growth and yield of rice and higher $\mathrm{N}$ use efficiency. NPK briquettes (2.4 $\mathrm{g} \times 2$ and $3.4 \mathrm{~g} \times 1$ ) gave statistically similar yield as USG and PU, but the former saved 33 $\mathrm{kg} \mathrm{ha}^{-1} \mathrm{~N}$ compared to prilled urea. The $3.4 \mathrm{~g} \times 1$ size NPK briquette showed $\mathrm{N}$ deficiency at later growth stage, because of lower $\mathrm{N}$ rates $(57 \mathrm{~kg})$. The P, K \& S application in some treatments had no effect on growth and yield of rice in that condition. So, it may be concluded that NPK briquette $(2.4 \mathrm{~g} \times 2)$ might be beneficial to the farmers in the tidal ecosystem.

\section{Acknowledgement}

The authors deeply acknowledge the sincere cooperation and assistance of Dr. M.A. Mazid Miah and Dr. Graham Hunter of ILSAFARM Project, IFDC, Barisal in conducting the experiment. 


\section{References}

Chandrajith R. K., Mahatantila H. A, Jayasena H. and Tobschall H. J. 2008. Geochemical characteristics of sediments from a reservoir (tank) ecosystem in Srilanka. Paddy Water Environment, 6:363-371.

Durguda A. G., Patil Y. J., Bulbula A. V. and Patil V. S. 2008. Effect of fertilizer management through urea-DAP briquettes on lowland rice. An Asian Journal of Soil Science, 3(1):1-3.

IFDC 2007. Mitigating poverty and environmental degradation through nutrient management in South Asia. IFDC Report, March 2007. International Fertilizer Development Centre.

IFPRI 2004. Annual Report, 2003-2004. International Food Policy Research
Institute (IFPRI): Wasington, DC, USA, $74 \mathrm{p}$.

Kadam J. R. 2001. Efficient use of NPK fertilizer briquettes on the yield and quality of crops. Indian Sugarcane, 51(2): 115-118.

Kapoor, V., Singh, U., Patil, S. K., Magre, H., Shrivastava, L. K., Mishra, V. N., Das, R. O. Samadhiya, V. K., Sanabria J. and Diamond, R. 2008. Rice Growth, Grain Yield and Floodwater Nutrient Dynamics as Affected by Nutrient Placement Method and Rate. Agronomy Journal. 100(3): 526-536.

Neubauer S. C, Anderson I. C, Constantine J. A. and Kuehl S. A. 2002. Sediment Deposition and Accretion in a Mid-Atlantic (U.S.A) Tidal Freshwater Marsh Estuarine. Coastal Shelf Science, 54: 713-727. 